International Journal of Current Advanced Research

ISSN: O: 2319-6475, ISSN: P: 2319 - 6505, Impact Factor: SJIF: 5.995

Available Online at www.journalijcar.org

Volume 6; Issue 4; April 2017; Page No. 3267-3269

DOI: http://dx.doi.org/10.24327/ijcar.2017.3269.0242

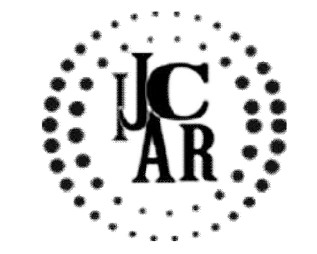

Research Article

\title{
REGULATORY GUIDELINES AND KEY ASPECTS OF GUIDELINES IN THE USE OF BIOLOGICS
}

\author{
Lakshmi Prabha J1* and Uma Maheswari T.N²
}

Saveetha Dental College and Hospitals, Saveetha University

\begin{tabular}{|c|c|}
\hline A $\quad R$ T I C L E I N F O & $A B S T R A C T$ \\
\hline Article History: & $\begin{array}{l}\text { Biologics are used in the treatment of immune mediated disease aimed a modulating } \\
\text { lymphocytes or cytokines. They can be categorized broadly into three categories: TNF- } \alpha\end{array}$ \\
\hline $\begin{array}{l}\text { Received } 16^{\text {th }} \text { January, } 2017 \\
\text { Received in revised form } 19^{\text {th }} \text { February, } 2017 \\
\text { Accepted } 22^{\text {nd }} \text { March, } 2017 \\
\text { Published online } 28^{\text {th }} \text { April, } 2017\end{array}$ & $\begin{array}{l}\text { inhibitors, lymphocyte modulators and interleukin inhibitors. Regulatory guidelines for the } \\
\text { development of biologics include validations of various steps in development, standard } \\
\text { guidelines, manufacturing guidelines, analytical tests. Hence, in this article the regulatory } \\
\text { guidelines and key aspects of guidelines in the use of biologics in oral medicine are } \\
\text { presented. }\end{array}$ \\
\hline
\end{tabular}

Key words:

Biologics, cytokines, guidelines, lymphocytes,

TNF- $\alpha$, interleukin.

Copyright $\bigcirc 2017$ Lakshmi Prabha J and Uma Maheswari T.N. This is an open access article distributed under the Creative Commons Attribution License, which permits unrestricted use, distribution, and reproduction in any medium, provided the original work is properly cited.

\section{INTRODUCTION}

Biologics treatments are innovative treatment aimed at TNF- $\alpha$ inhibitors, IL inhibitors and lymphocyte modulators. They have several potential applications in oral medicine and are increasingly used in treating patient with only refractory forms of inflammatory immune-mediated diseases. [1][2][3] Biologics are generated by recombinant technology and comprises a large number of monoclonal antibodies and fusion proteins which act by targetting specific proinflammatory pathways. Guidelines for the use of biologicsin licensed indications include use of biologics in off-label situations, eligibility for use, adverse effects, infection control andtheir relevance to oral medicine. ${ }^{[1]}$ Regulatory guidelines for the development of biologics include validations of various steps in development, standard guidelines, manufacturing guidelines, analytical tests. Biologics can be used therapeutically in patients who have no alternate approach whoever is not used widely due to its high economic cost. ${ }^{[2]}$

\section{Regulatory Guidelines for the Development of Biologics}

\section{Validation of each step of development of biologics}

The various steps involved in the process of development of biologics are: selection of target, target validation, screening preparation, hit generation \& lead selection, lead optimisation $\&$ characterisation and candidate selection. ${ }^{[4]}$

*Corresponding author: Lakshmi Prabha J Saveetha Dental College and Hospitals, Saveetha University

\section{SOP Guidelines}

Standard Operating Procedure guidelines are a sequential procedure provided for manufacture and development of biologics which is essential for the quality. It should minimum include: title page, header, department name, effective date, revision date, review date, page no, regulatory basis, reference documents, purpose, scope, responsibilities \& accountabilities, procedure, footer and stamp. ${ }^{[5]}$

\section{CMC Guidelines}

Chemistry, Manufacturing and Control (CMC) guidelines include the information regarding the manufacture, stability and controls used in the manufacture of biologics. The assessment of CMC should include adequate characterisation of the biologic, adequate characterisation of impurities, adequate description of manufacturing, facilities available for manufacturing, quality control measures and acceptable supporting information. ${ }^{[6]}$

\section{Analytical tests to assess identity, purity and concentrations}

The success of development of biologics depends on the utilisation of correct analytical methods for identification, purity analysis and concentrations. Chromatographic methods, spectroscopic techniques, peptide mapping are primarily used. Chromatographic methods are used for characterization of biophysical and chemical properties, formulation development and in release testing and are common tools for physical and also chemical degradation. Spectroscopic techniques are used for qualitative and quantitative analysis of conformational structure of proteins, their behaviour, and their stability in development and release. Peptide mapping is used for identification and purity testing 
which includes determination of primary amino acid chain, intact peptide fragments along with identification of specific degradation site.
In patients with viral infections screening must be done prior to treatment with TNF- $\alpha$ because viral reactivation may occur.

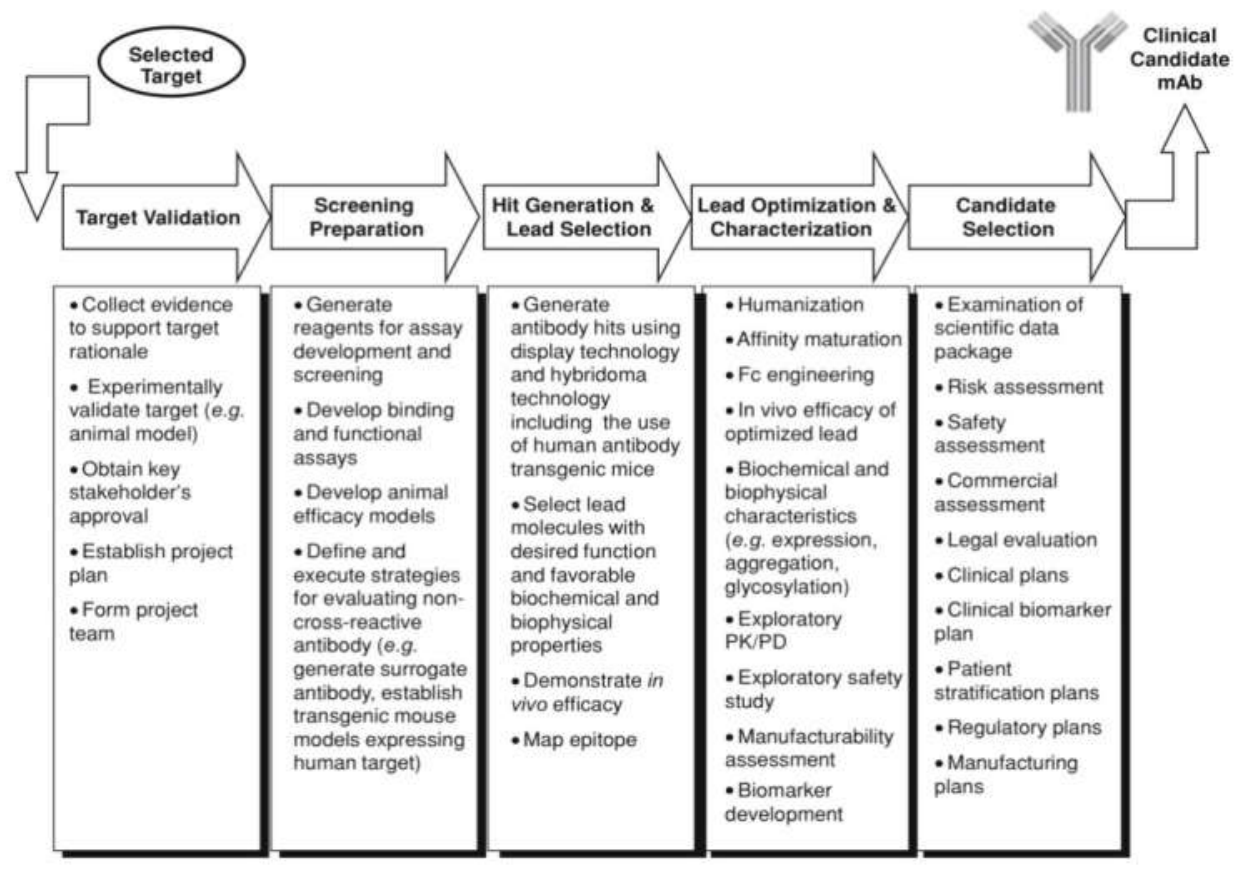

Other techniques include isoelectric focusing and capillary isoelectric focusing, SDC-PAGE, thermal analysis, particulate matter analysis, Karl-Fischer titration and thermo-gravimetric analysis. ${ }^{[7]}$

\section{Properties of biologics}

Biologics have properties such as self-association of the protein, dependence on molar absorption co-efficient, solubility, $\mathrm{pH}$ stability, thermal stability and shear stability. Early propensities to form reversible and irreversible aggregates have significant effect on development of biologics. $\mathrm{pH}$ solubility is an important aspect which along with $\mathrm{pH}$ stability plays a key role in the development of biologics. Instability in storage conditions may lead to distortion and other conformational changes. Hence biologics should have a thermal stability in addition to shear stability. ${ }^{[8]}$

\section{Key Aspects of Guidelines for Biologics}

\section{On the use ofTNF- $\alpha$ Inhibitors}

TNF- $\alpha$ is a key pro-inflammatory cytokine secreted by the Tcells and macrophages which is a pleotropic actions that can be present both as a trans-membrane protein and a soluble cytokine.It promotes increased leukocyte activity and has a significant role in the pathogenesis of immune mediated disease through various pathways. Apart from oral diseases like aphthous ulceration, oral CD, orofacial granulomatosis, pemphigus vulagaris, Sjogren's syndrome, they have also been used to treat psoriasis and rheumatoid arthritis.

Administration mode for TNF- $\alpha$ inhibitors are similar to other biologic agents in the form of injected preparations with varying schedules. Infliximab must be given as periodic intravenous infusions whereas etanercept and adalimumab are given as regular subcutaneous injections biweekly. Although it is associated with greater incidence of adverse effects, it is based on cost and potential risks. ${ }^{[9]}$
Anti-TNF therapy is given along with ART only in controlled cases of HIV infections where immune-competence is not low and CD-4 count is under monitoring. Anti-TNF therapy may also cause reactivation of mycobacterial infections and screening is done prior to treatment. Risk of TB is increased in patients receiving infliximab and adalimumab and routine screening is essential. Immunization and application of vaccines are of main concern since TNF- $\alpha$ inhibition causes risk of severe or fatal infections due to vital replication. Patients should receive influenza and pneumococcal immunizations prior to therapy for RA. ${ }^{[2]}$

\section{On the use of Lymphocyte modulators}

Lymphocyte modulators are immune regulating polypeptides which regulates CD-4 lymphocyte production and function. It is a single chain polypeptide with a cationic glycoprotein which has a molecular weight of 50,000 daltons. The protein was shown to augment the immune responses of both the immature and mature T-cells and hence was knownas Lymphocyte T-cell immunomodulator.The bovine protein used is prepared in a lyophilised 1 microgram dose and its reconstruction in a sterile diluent produces a solution that is used to treat subcutaneous infections.

They can also be administered through injection preparations. Rituximab must be given as periodic intravenous infusions biweekly whereas alefacept is given as intramuscular injections weekly. Lymphocyte modulators can be differentiated as T-cell immunomodulators and B-cell immunomodulators.B-cell modulators have some effects upon T-cells. Rituximab has specific effect on mature B-cells and acts by targeting CD-20 selectively depleting all circulating B-cells. T-cell modulators have an effect on specific CD antigens. Alefacept targets memory T-cells and NK cells blocking CD2 interaction in antigen presentation and inducing T-cell apoptosis. Screening for viral disease is done prior to treatment with rituximab. Rituximab can be given in case of 
HIV and its associated infections but alefacept is strictly contraindicated since it reduces CD-4 count. TB Screening is not necessary in patients with RA receiving rituximab. Rituximab should not be given in patients with serious or opportunistic infections however definitive guidance is unclear with regards to rituximab. Rituximab causes severe infections and lowers IgG levels and hence should be used with caution. ${ }^{[2]}$

\section{On the use of IL-Inhibitors}

Interleukin inhibitors are immunosuppressive agents which inhibits the action of interleukins in regulating the immune system. There are various types of interleukins. The inhibitors of interleukin 1 like anakinra, rilonacept or canakinumab are used to treat diseases of joint, bone, muscles as well as autoinflammatory and inflammatory diseases. ${ }^{[10]}$ Interleukin 6 is a pleotropic cytokine which when inhibited is effective in case of rheumatoid arthritis. Tocilizumab is a monoclonal antibody which is specific and the first biologic agent targeting IL-6. ${ }^{[11]}$ Although it is effective in the treatment of RA along with TNF- $\alpha$ inhibitors, its use is contraindicated when used with etanercept due to its reduced efficacy. ${ }^{[12]}$ Anakinra must not be used with TNF- $\alpha$ inhibitors like etanercept, infliximab, adalimumab. Tocilizumab should not be given during acute infections and latent stage of TB. ${ }^{[13]}$

\section{CONCLUSION}

Thus this article emphasizes the important aspects of guidelines forthe use of biologics in the treatment of various immune mediated diseases which otherwise does not have any other treatment and the regulatory guidelines for its use. Although they have adverse effects in some patients they can be used in recommended doses in patients whom other therapies have failed. Hence it is important to know the regulatory guidelines and key aspects of guidelines for the use of biologics for safe and effective treatment of oral and other immune mediated inflammatory conditions.

\section{References}

1. Eleni A. Georgakopoulou, DimitriosAndreadis, EfthymiosArranitidis, PanagiotaLoumou; Biologic agents and oral diseases-An update on clinical applications; ActaDermatovenerol Croat, 2013; 21(1);24-34.

2. ID O'Neill, C Scully; Biologics in oral medicine: principles of use and practice considerations; Oral diseases (2012) 18, 525-536.

3. Iain David O'Neilli; Off-label use of biologics in the management of oral mucosal diseases; J Oral Pathol Med, 2008 Nov; 37(10); 575-81.

4. Heather H.Shih; Discovery process for antibody-based therapeutics; Bio Therapeutics research 2012.

5. Biologics development: physicochemical and biophysical characterisation; Wolfe laboratories.

6. Therapeutic products directorate; Lourenco 2008.

7. Biologics development: analytical; Wolfe laboratories.

8. Biologics development: properties; Wolfe laboratories.

9. Jackson JM; TNF- $\alpha$ inhibitors; Dermatol Ther 2007; 20; 251-64.

10. Beardsley, Terry R; Method to enhance haematopoiesis; Patent \#7 196, 060.

11. Kallioloas GD, Liossis SN; The future of IL-1 receptor antagonist anakinra from rheumatoid arthritis to adult onset Still's disease and systemic onset juvenile idiopathic arthritis; Expert OpinInvestig Drugs; 17(3): 349-59 Mar 2008.

12. Virginia Pascual, Florence Allantaz, EdselArce, Marilynn Punaro, Jacques Banchereau; Role of IL-1 in the pathogenesis of systemic onset juvenile idiopathic arthritis and clinical response to IL-1 blockade; $J$ Exp Med. 2005 May 2; 2019; 1479-1486.

13. Avril A. Fitzgerald, Sharon A. LeClercq, Alexander Yan, Joanne E. Homik, Charles A. Dinarello: Rapid responses to anakinra in patients with refractory adultonset Still's disease; Arthritis Rheum 2005 Jun; 52(6); 1794-1803.

\section{How to cite this article:}

Lakshmi Prabha J and Uma Maheswari T.N (2017) ' Regulatory Guidelines And Key Aspects Of Guidelines In The Use Of Biologics', International Journal of Current Advanced Research, 06(04), pp. 3267-3269.

DOI: http://dx.doi.org/10.24327/ijcar.2017.3269.0242 